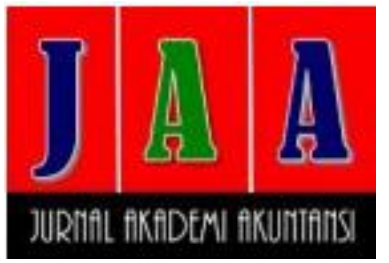

\title{
PERAN PERANGKAT DESA DALAM AKUNTABILITAS PENGELOLAAN DANA DESA
}

\author{
Ulfah Andriani, Tatik Zulaika* \\ Program Studi Akuntansi, Fakultas Ekonomi dan Bisnis \\ Universitas Palangkaraya
}

Jl. Yos Sudarso, Palangka, Kec. Jekan Raya, Kota Palangka Raya, Kalimantan Tengah

*Corresponding author: tatikzlk19@gmail.com

\begin{abstract}
A large budget allocation has consequences for its management which should be carried out professionally, effectively, efficiently, and accountably. Considering the amount of funds received by the villages is large and increasing every year, it is necessary role of village apparatus to assist the village head in managing the village fund. This research aims to know the role of village apparatus in accountability of village fund management in Batu Raya I village, Timang which includes Implementation, Reporting and Accountability.

This research is a Descriptive Research with a Qualitative Approach that uses Primary Data and Secondary Data as the data source. The resource persons consist of Village Head, Village Secretary, Finance Chief, Chief of Development, and Treasurer. Data collection techniques were conducted with Interviews and documentation. Data analysis techniques ranging from data summarization, data presentation, and conclusions.

The results of this study indicate that the Village Tool has played a role in the management of village funds and the implementation, reporting, and accountability have implemented the principle of accountability. However, there is still a need for further guidance because it is not fully in accordance with the provisions of the legislation.

We recommend that the existing Village Devices in Batu Raya I Village increase their knowledge about Village Fund Management, must optimize their duties and functions and continue to maintain Accountability that has been run and built together, and the North Barito District Government should hold community development activities on financial management village and use of SISKEUDES application.
\end{abstract}

Diterima : 21 Agustus 2019

Direview : 10 Oktober 2019

Direvisi : 16 November 2019

Diterima : 30 November 2019

Artikel ini tersedia di website :

http://ejournal.umm.ac.i d/index.php/jaa

\section{Keywords: Village Fund (DD), Role of Village Devices, Accountability}

\section{PENDAHULUAN}

Sejak diberlakukannya Undang-Undang Nomor 6 Tahun 2014 tentang Desa,desa diberi wewenang oleh pemerintah pusat untuk mengatur dan mengembangkan daerahnya sendiri. Kebijakan alokasi anggaran yang besar memiliki konsekuensi terhadap pengelolaannya yang seharusnya dilaksanakan secara professional, efektif, efisien, serta akuntabel. Mengingat dana yang di terima oleh desa jumlahnya cukup besar dan semakin meningkat setiap tahunnya, maka diperlukan peran perangkat desa untuk membantu kepala desa dalam mengelola dana desa. 
Penelitian ini bertujuan untuk mengetahui Peran Perangkat Desa Dalam Akuntabilitas Pengelolaan Dana Desa Di Desa Batu Raya I Kecamatan Gunung Timang yang meliputi Pelaksanaan, Pelaporan, Dan Pertanggungjawaban. penelitian ini dapat dijadikan suatu referensi maupun tinjauan secara nyata yang mendeskripsikan sejauh mana kinerja pemerintah untuk mewujudkan Good Government dan Governance dan diharapkan menjadi referensi pegawai maupun pihak-pihak yang ada dalam Pemerintah Desa agar senantiasa bekerja secara transparan dan akuntabel yang bersih dan berwibawa.

Pada penelitian terdahulu yang dilakukan oleh Neny Tri Indrianasari dan Kadek Sutrawati Perangkat Desa cukup berperan dalam pengelolaan keuangan desa dan secara keseluruhan pelaksanaan Pengelolaan Keuangan Desa sesuai dengan Permendagri Nomor 113 Tahun 2014, penelitian yang dilakukan oleh Restiana Putri Rahayu Peran BPD dalam pengelolaan dana desa antara lain menyampaikan gagasan mengenai pengelolaan dana desa sebagai wujud penampungan aspirasi masyarakat sebagai penentu prioritas pelaksanaan pengelolaan dana desa dengan pertimbangan kepala desa. Dan pada penelitian yang dilakukan oleh Arie Rekza Cahya Profesionalitas aparatur desa dalam pelaksanaan alokasi dana desa di desa Adi Jaya yang diukur melalui enam indikator yang menetukan profesionalitas dapat dikatakan sudah terpenuhi walaupun belum maksimal. Namun pada indikator disiplin kerja dapat dikatakan kurang terpenuhi dan perlu dilakukan perbaikan. Mengenai akuntabilitas Aparatur Kampung dalam pelaksanaan alokasi dana di Kampung Adi Jaya dapat dikatakan terlaksana dengan baik secara keseluruhan.

Penelitian ini menunjukkan bahwa Perangkat Desa sudah berperan dalam pengelolaan dana desa dan pelaksanaan, pelaporan, dan pertanggungjawaban sudah melaksanakan prinsip akuntabilitas. Namun masih diperlukan adanya pembinaan lebih lanjut karena belum sepenuhnya sesuai dengan ketentuan perundang-undangan.

Keterbatasan pada penelitian ini yaitu penelitian ini hanya membahas pengelolaan dana desa yang meliputi pelaksanaan, pelaporan dan pertanggungjawaban. Sehingga bagi Peneliti Selanjutnya, diharapkan dapat membahas pengelolaan dana desa secara detail dan mendalam karena kelemahan pada penelitian ini yaitu kurangnya pembahasan secara mendalam.

\section{LANDASAN TEORI \\ Definisi Desa}

Berdasarkan UU Nomor 6 tahun 2014 tentang desa, Desa adalah desa dan desa adat atau yang disebut dengan nama lain, selanjutnya disebut Desa, adalah kesatuan masyarakat hukum yang memiliki batas wilayah yang berwenang untuk mengatur dan mengurus urusan pemerintahan, kepentingan masyarakat setempat berdasarkan prakarsa masyarakat, hak asal usul, dan/atau hak tradisional yang diakui dan dihormati dalam sistem pemerintahan Negara Kesatuan Republik Indonesia. 


\section{Definisi Pemerintah Desa}

Menurut Peraturan Pemerintah Nomor 113 Tahun 2014 Pemerintahan Desa adalah penyelenggaraan urusan pemerintahan dan kepentingan masyarakat setempat dalam sistem pemerintahan Negara Kesatuan Republik Indonesia.

Berdasarkan Undang-undang Nomor 6 Tahun 2014 Pemerintah desa adalah kepala desa atau yang disebut dengan nama lain yang dibantu oleh perangkat desa sebagai unsur penyelenggara pemerintahan desa. Sesuai penjelasan UU Nomor 6 Tahun 2014, kepala desa atau yang disebut dengan nama lain merupakan kepala pemerintahan desa yang memimpin penyelenggaraan pemerintahan desa. Kepala desa yang disebut nama lain memiliki peran penting dalam kedudukannya sebagai kepanjangan tangan negara yang dekat dengan masyarakat desa dan sebagai pemimpin masyarakat desa. Pemerintah desa terdiri dari kepala desa dan perangkat desa yang meliputi sekretaris desa dan perangkat desa lainnya.

\section{Peran Perangkat Desa}

Menurut Kamus Besar Bahasa Indonesia, peran didefinisikan sebagai seperangkat tingkat yang diharapkan dimiliki oleh orang yang berkedudukan dalam masyarakat. Peran merupakan aspek dinamis dari kedudukan (status) yang dimiliki oleh seseorang. Hakekatnya peran juga dapat dirumuskan sebagai suatu rangkaian perilaku tertentu yang ditimbulkan oleh suatu jabatan tertentu. Kepribadian seseorang juga mempengaruhi bagaimana peran itu harus dijalankan. Peran yang dimainkan hakekatnya tidak ada perbedaan, baik yang dimainkan / diperankan pimpinan tingkat atas, menengah maupun bawah akan mempunyai peran yang sama.

Menurut Ndraha (1991 : 152), Kepala Desa sebagai wakil pemerintah di desa yang bersangkutan adalah penguasa tunggal dalam arti:

1) Memimpin pemerintahan desa.

2) Mengkoordinasikan pembangunan desa.

3) Membina kehidupan masyarakat di segala bidang.

Menurut Widjaja (2002: 22) yang dimaksud dengan perangkat desa adalah:

a. Unsur Staf, yaitu unsur pelaksana kesekretariatan (sekretaris desa) bertanggungjawab kepada kepala desa.

1) Sekretaris desa berkedudukan sebagai:

a) Urusan staf sebagai orang kedua;

b) Memimpin sekretariat desa.

2) Tugas sekretaris desa

a) Memberikan pelayanan staf;

b) Melaksanakan administrasi desa.

3) Fungsi sekretaris desa

a) Kegiatan surat-menyurat, kearsipan dan pelaporan;

b) Kegiatan pemerintahan dan keuangan desa;

c) Administrasi kependudukan;

d) Administrasi umum;

e) Melaksanakan fungsi kepala desa apabila berhalangan. 
b. Unsur pelaksana teknis, yaitu kepala urusan, bertanggungjawab kepada sekretaris desa

1) Kedudukan kepala urusan adalah sebagai unsur pembantu sekretaris desa dalam bidang tugasnya.

2) Tugas kepala urusan adalah membantu sekretaris desa dalam bidang tugasnya.

3) Fungsi kepala urusan adalah:

a) Kegiatan sesuai dengan unsur bidang tugas;

b) Pelayanan administrasi terhadap kepala desa.

c. Unsur wilayah, adalah kepala dusun yang membantu kepala desa di wilayah bagian desa dan bertanggungjawab kepada kepala desa.

1) Kedudukan kepala dusun adalah sebagai pelaksana tugas kepala desa di wilayahnya.

2) Tugas kepala dusun adalah melaksanakan tugas-tugas di wilayah kerjanya.

3) Fungsi kepala dusun adalah:

a) Melaksanakan kegiatan pemerintahan, pembangunan, dan kemasyarakatan;

b) Melaksanakan keputusan desa di wilayah kerjanya;

c) Melaksanakan kebijaksanaan kepala desa.

Menurut Permendagri Nomor 113 Tahun 2014 Tentang Pengelolaan Keuangan Desa Pelaksana Teknis Pengelolaan Keuangan Desa yang selanjutnya disingkat PTPKD adalah unsur perangkat desa yang membantu Kepala Desa untuk melaksanakan pengelolaan keuangan desa yang terdiri dari: Sekretaris Desa, Kepala Seksi, dan Bendahara. PTPKD sebagaimana dimaksud pada ayat (1) ditetapkan dengan Keputusan Kepala Desa.

\section{Akuntabilitas}

Menurut Setiyono (2014: 193) akuntabilitas adalah prinsip yang menekankan bahwa segala perilaku, kebijakan, dan kegiatan institusi publik selalu dapat dipertanggungjawabkan dalam kerangka kepentingan publik. Tidak boleh ada sedikitpun fasilitas, anggaran, dan kewenangan yang dimiliki, digunakan bagi sesuatu yang bertujuan untuk kepentingan pribadi maupun kelompok.

Menurut Mahmudi (2015: 9) Akuntabilitas yaitu kewajiban untuk mempertanggungjawabkan apa yang telah dilakukan atau tidak dilakukan oleh seseorang dan harus diikuti dengan pemberian kapasitas untuk melaksanakan, keleluasaan (diskresi) dan kewenangan.

Menurut Kohler dalam Waluyo (2007: 191) akuntabilitas didefinisikan sebagai kewajiban seseorang, agen, atau orang lain untuk memberikan laporan yang memuaskan secara periodik atas tindakan atau atas kegagalan untuk bertindak dari otorisasi atau wewenang yang dimiliki.

Jadi akuntabilitas merupakan pertanggungjawaban seseorang terhadap pelaksanaan wewenang yang dimilikinya, agar kewenangan tersebut digunakan sesuai dengan kepentingan organisasi dan mencegah terjadinya penyalahgunaan wewenang untuk kepentingan pribadi. 
Menurut Hopwood dan Tomkins dalam Mahmudi (2015: 9-11) menjelaskan bahwa akuntabilitas publik yang harus dilakukan oleh organisasi sektor publik terdiri atas beberapa aspek. Dimensi akuntabilitas yang harus dipenuhi oleh lembaga-lembaga publik tersebut antara lain:

1. Akuntabilitas Hukum dan Kejujuran

Akuntabilitas hukum dan kejujuran adalah akuntabilitas lembaga-lembaga publik untuk berperilaku jujur dalam bekerja dan menaati peraturan hukum yang berlaku. Penggunaan dana publik harus dilakukan secara benar dan telah mendapatkan otorisasi.

2. Akuntabilitas Manajerial

Akuntabilitas manajerial adalah pertanggungjawaban lembaga publik untuk melakukan pengelolaan organisasi secara efisien dan efektif. Akuntabilitas manajerial dapat juga diartikan sebagai akuntabilitas kinerja (performance accountability). Inefisiensi organisasi publik adalah menjadi tanggung jawab lembaga yang bersangkutan dan tidak boleh dibebankan kepada klien atau customer-nya. Akuntabilitas manajerial juga berkaitan dengan akuntabilitas proses (process accountability) yang berarti bahwa proses organisasi harus dapat dipertanggungjawabkan, dengan kata lain tidak terjadi inefisiensi dan ketidakefektifan organisasi.

3. Akuntabilitas Program

Akuntabilitas program berkaitan dengan pertimbangan apakah tujuan yang ditetapkan dapat dicapai atau tidak, dan apakah organisasi telah mempertimbangkan alternatif program yang memberikan hasil yang optimal dengan biaya yang minimal. Lembaga-lembaga publik harus mempertanggungjawabkan program yang telah dibuat sampai pada pelaksanaan program. Dengan kata lain akuntabilitas program berarti bahwa program-program organisasi hendaknya merupakan program yang bermutu yang mendukung strategi dan pencapaian, visi, misi dan tujuan organisasi.

4. Akuntabilitas Kebijakan

Akuntabilitas kebijakan terkait dengan pertanggungjawaban lembaga publik atas kebijakan-kebijakan yang diambil. Lembaga-lembaga publik hendaknya dapat mempertanggungjawabkan kebijakan yang telah ditetapkan dengan mempertimbangkan dampak di masa depan. Dalam membuat kebijakan harus mempertimbangkan apa tujuan kebijakan tersebut, mengapa kebijakan itu diambil, siapa sasarannya, pemangku kepentingan (stakeholder) mana yang akan terpengaruh dan memperoleh manfaat dan dampak (negatif) atas kebijakan tersebut.

5. Akuntabilitas Finansial

Akuntabilitas finansial adalah pertanggungjawaban lembaga-lembaga publik untuk menggunakan uang publik (publik money) secara ekonomi, efisien, dan efektif, tidak ada pemborosan dan kebocoran dana serta korupsi. Akuntabilitas finansial menekankan pada ukuran anggaran dan finansial. Akuntabilitas finansial sangat penting karena pengelolaaan keuangan publik akan menjadi perhatian utama masyarakat. 


\section{Dana Desa}

Berdasarkan PP No. 60 tahun 2014, dana desa adalah dana yang bersumber dari Anggaran Pendapatan dan Belanja Negara yang diperuntukkan bagi desa yang ditransfer melalui Anggaran Pendapatan dan Belanja Daerah (APBD) kabupaten/kota dan digunakan untuk membiayai penyelenggaraan pemerintahan, pelaksanaan pembangunan, pembinaan kemasyarakatan dan pemberdayaan masyarakat. PP No. 60 Tahun 2014 ini kemudian direvisi kembali melalui PP No. 22 Tahun 2015. Substansi yang dirubah dalam PP No. 60 Tahun 2014 ke PP No. 22 Tahun 2015 adalah pada formula alokasi atau pembagian dana desa dari pusat ke kabupaten dan dari kabupaten ke desa.

\section{Pengelolaan Dana Desa}

\section{Perencanaan}

Pemerintah desa menyusun perencanaan pembangunan desa sesuai dengan kewenangannya dengan mengacu pada perencanaan pembangunan kabupaten dan kota. Rencana pembangunan desa disusun untuk menjamin keterkaitan dan kosistensi antara perencanaan, penganggaran, pelaksanaan, dan pengawasan (Sujarweni, 2015:18).

Mekanisme perencanaan menurut Permendagri No 113 Tahun 2014 adalah sebagai berikut:

1. Sekretaris desa menyusun Rancangan Peraturan Desa tentang APBDesa berdasarkan RKPDesa. Kemudian Sekretaris Desa menyampaikan kepada Kepala Desa.

2. Rancangan Peraturan Desa tentang APBDesa disampaikan Kepala Desa kepada Badan Permusyawaratan Desa untuk pembahasan lebih lanjut.

3. Rancangan tersebut kemudian disepakati bersama, dan kesepakatan tersebut paling lama bulan oktober tahun berjalan.

4. Rancangan Peraturan Desa tentang APBDesa yang telah disepakati bersama, kemudian disampaikan oleh Kepala Desa kepada Bupati/Walikota melalui Camat atau sebutan lain paling lambat tiga hari sejak disepakati untuk dievaluasi. Bupati/Walikota dapat mendelegasikan evaluasi Rancangan Peraturan Desa tentang APBDesa kepada Camat atau Sebutan Lain.

5. Bupati/Walikota menetapkan hasil evaluasi Rancangan APBDesa paling lama 20 hari kerja sejak diterimanya Rancangan Peraturan Desa tentang APBDesa. Jika dalam waktu 20 hari kerja Bupati/Walikota tidak memberikan hasil evaluasi maka peraturan desa tersebut berlaku dengan sendirinya.

6. Jika kepala desa melakukan penyempurnaan paling lama 7 hari kerja terhitung sejak diterimanya hasil evaluasi.

7. Apabila Bupati/Walikota menyatakan hasil evaluasi Rancangan Peraturan Desa tentang APBDesa tidak sesuai dengan kepentingan umum dan peraturan perundang-undangan yang lebih tinggi, maka kepala desa melakukan penyempurnaan paling lama 7 hari kerja terhitung sejak diterimanya hasil evaluasi. 
8. Apabila hasil evaluasi tidak ditindaklanjuti oleh Kepala Desa dan Kepala Desa tetap menetapkan Rancangan Peraturan Desa tentang APBDesa menjadi peraturan Desa, Bupati/Walikota membatalkan Peraturan Desa dengan Keputusan Bupati/Walikota.

9. Pembatalan Peraturan Desa, sekaligus menyatakan berlakunya pagu APBDesa tahun anggaran sebelumnya. Dalam hal pembatalan, Kepala Desa hanya dapat melakukan pengeluaran terhadap operasional penyelenggaraan Pemerintah Desa.

10. Kepala Desa memberhentikan pelaksanaan Peraturan Desa paling lama 7 hari kerja setelah pembatalan dan selanjutnya Kepala Desa bersama BPD mencabut Peraturan Desa dimaksud.

\section{Pelaksanaan}

Dalam pelaksanaan anggaran desa yang sudah ditetapkan sebelumnya timbul transaksi penerimaan dan pengeluaran desa. Semua penerimaan dan pengeluaran desa dalam rangka pelaksanaan kewenangan desa dilaksanakan melalui rekening kas desa. Jika yang belum memiliki pelayanan perbankan di wilayahnya maka pengaturannya ditetapkan oleh Pemerintah Kabupaten/Kota.Semua penerimaan dan pengeluaran desa harus didukung oleh bukti yang lengkap dan sah (Sujarweni, 2015:19).

Beberapa aturan dalam pelaksanaan pengelolaan keuangan desa:

1. Pemerintah desa dilarang melakukan pungutan sebagai penerimaan desa selain yang ditetapkan dalam peraturan desa.

2. Bendahara dapat menyimpan uang dalam kas desa pada jumlah tertentu dalam rangka memenuhi kebutuhan operasional pemerintah desa.

3. Pengaturan jumlah uang dalam kas desa ditetapkan dalam peraturan Bupati/Walikota.

4. Pengeluaran desa yang mengakibatkan beban pada APBDesa tidak dapat dilakukan sebelum Rancangan Peraturan Desa tentang APBDesa ditetapkan menjadi Peraturan Desa.

5. Pengeluaran desa tidak termasuk untuk belanja pegawai yang bersifat mengikat dan operasional perkantoran yang ditetapkan dalam peraturan Kepala Desa.

6. Penggunaan biaya tak terduga terlebih dahulu harus dibuat Rincian Anggaran Biaya yang telah disahkan oleh Kepala Desa.

7. Pengadaan kegiatan yang mengajukan pendanaan untuk melaksanakan kegiatan harus disertai dengan dokumen antara lain Rencana Anggaran Biaya.

8. Rencana Anggaran Biaya diverifikasi oleh sekretaris Desa dan disahkan oleh Kepala Desa.

9. Pelaksana kegiatan bertanggungjawab terhadap tindakan pengeluaran yang menyebabkan atas beban anggaran belanja kegiatan dengan mempergunakan buku pembantu kas kegiatan sebagai pertanggungjawaban pelaksanaan kegiatan desa. 
10. Pelaksana kegiatan mengajukan Surat Permintaan Pembayaran (SPP) kepada Kepala Desa. Surat Permintaan Pembayaran (SPP) tidak boleh dilakukan sebelum barang dan atau jasa diterima. Pengajuan SPP trdiri atas Surat Permintaan Pembayaran (SPP), Pernyataan tanggungjawab belanja; dan lampiran bukti transaksi.

11. Berdasarkan SPP yang diverifikasi Sekretaris Kepala Desa kemudian Kepala Desa menyetujui permintaan pembayaran dan bendahara melakukan pembayaran.

12. Pembayaran yang telah dilakukan akan dicatat bendahara.

13. Bendahara desa sebagai wajib pungut Pajak Penghasilan (PPh) dan pajak lainnya, wajib menyetorkan seluruh penerimaan potongan dan pajak yang dipungutnya ke rekening kas Negara sesuai dengan peraturan perundangundangan.

\section{Penatausahaan}

Penatausahaan merupakan kegiatan pencatatan yang khususnya dilakukan oleh bendahara desa. Media penatausahaan berupa buku kas umum, buku pajak, buku bank serta setiap bulan membuat laporan pertanggungjawaban bendahara.

Kepala desa dalam melaksanakan penatausahaan keuangan desa harus menetapkan bendahara desa. Penetapan bendahara desa harus dilakukan sebelum dimulainya tahun anggaran bersangkutan dan berdasarkan keputusan kepala desa. Bendahara adalah perangkat desa yang ditunjuk oleh kepala desa untuk menerima, menyimpan, menyetorkan, menatausahakan, membayar, dan mempertanggungjawabkan keuangan desa dalam rangka pelaksanaan APBDes (Hamzah, 2015 : 35). Bendahara desa wajib mempertanggungjawabkan uang melalui laporan pertanggungjawaban. Laporan pertanggungjawaban disampaikan setiap bulan kepada Kepala Desa dan paling lambat tanggal 10 bulan berikutnya.

Menurut Permendangri Nomor 113 Tahun 2014 laporan pertanggungjawaban yang wajib dibuat oleh bendahara desa adalah:

1) Buku Kas Umum

Buku Kas Umum digunakan untuk mencatat berbagai aktifitas yang menyangkut penerimaan dan pengeluaran kas, baik secara tunai maupun kredit, digunakan juga untuk mencatat mutasi perbankan atau kesalahan dalam pembukuan. Buku kas umum dapat dikatakan sebagai sumber dokumen transaksi.

2) Buku Kas Pembantu Pajak

Buku pajak digunakan untuk membantu buku kas umum, dalam rangka penerimaan dan pengeluaran yang berhubungan denga pajak.

3) Buku Bank

Buku bank digunakan untuk membantu buku kas umum, dalam rangka penerimaan dan pengeluaran yang berhubungan dengan uang bank.

\section{Pelaporan}

Menurut Permendagri Nomor 113 Tahun 2014 dalam melaksanakan tugas, kewenangan, hak dan kewajiban, kepala desa wajib: 
1. Menyampaikan laporan realisasi APBDesa kepada Bupati/Walikota berupa:

a) Laporan semester pertama berupa laporan realisasi APBDesa, disampaikan paling lambat pada akhir bulan Juli tahun berjalan.

b) Laporan semester akhir tahun, disampaikan paling lambat pada akhir bulan januari tahun berikutnya.

2. Menyampaikan Laporan Penyelenggaraan Pemerintahan Desa (LPPD) setiap akhir tahun anggaran kepada Bupati/Walikota.

3. Menyampaikan Laporan Penyelenggaraan Pemerintahan Desa pada akhir masa jabatan kepada Bupati/Walikota.

4. Menyampaikan laporan keterangan penyelenggaraan pemerintah desa secara tertulis kepada BPD setiap akhir tahun anggaran.

\section{Pertanggungjawaban}

Permendagri Nomor 113 Tahun 2014 pertanggungjawaban terdiri dari:

1. Kepala desa menyampaikan laporan pertanggungjawaban realisasi pelaksanaan APBDesa kepada Bupati/Walikota melalui camat setiap akhir tahun anggaran. Laporan pertanggungjawaban pelaksanaan realisasi pelaksanaan APBDesa terdiri dari pendapatan, belanja, dan pembiayaan. Laporan ini ditetapkan peraturan desa dan dilampiri:

a) Format Laporan Pertanggungjawaban Realisasi Pelaksanaan APBDesa Tahun anggaran berkenaan.

b) Format Laporan Kekayaan Milik Desa per 31 Desember Tahun Anggaran berkenaan.

c) Format Laporan Program Pemerintah dan Pemerintah Daerah yang masuk ke Desa.

2. Laporan pertanggungjawaban realisasi pelaksanaan APBDesa sebagaimana dimaksud diatas, disampaiakan paling lambat 1 (satu) bulan setelah akhir tahun anggaran berkenaan.

\section{METODE PENELITIAN}

\section{Jenis Penelitian}

Jenis penelitian ini adalah penelitian kualitatif dengan pendekatan analisis deskriptif. Husaini dan Purnomo (2009) mengatakan bahwa penelitian deskriptif kualitatif adalah menguraikan pendapat responden apa adanya sesuai dengan pertanyaan penelitian, kemudian dianalisis dengan kata-kata yang melatarbelakangi responden berperilaku seperti itu, direduksi, ditriangulasi, disimpulkan, dan diverifikasi.

\section{Sumber Data}

Sumber data yang digunakan dalam penelitian ini yaitu:

1. Data Primer

Data primer merupakan sumber data penelitian yang di peroleh secara langsung dari objek penelitian.Dalam penelitian ini yang mejadi data primer adalah hasil jawaban wawancara yang digunakan pada penelitian ini. 


\section{Data Sekunder}

Data sekunder merupakan data yang berupa data-data yang telah tesedia yang dapat diperoleh peneliti. Dalam penelitian ini yang menjadi data sekunder yaitu data yang diperoleh melalui jurnal dan informasi yang langsung diperoleh dari lokasi penelitian.

\section{Teknik Pengumpulan Data}

\section{Wawancara}

Esterberg dalam Sugiyono (2009: 231) mendefinisikan wawancara merupakan pertemuan dua orang untuk bertukar informasi dan ide melalui tanya jawab , sehingga dapat dikonstruksikan makna dalam suatu topik tertentu. Wawancara pada penelitian ini adalah wawancara terbuka yaitu wawancara yang dilakukan dengan tidak merahasiakan narasumbernya dan juga memiliki pertanyaan-pertanyaan yang tidak terbatas atau tidak terikat jawabannya. Narasumber yang di wawancarai pada penelitian ini adalah kepala desa dan perangkat desa yang terdiri dari sekretaris desa, kaur keuangan, kaur pembangunan, dan bendahara. Wawancara dilakukan dengan berpedoman pada pengelolaaan dana desa yang meliputi pelaksanaan, pelaporan, pertanggungjawaban, dan berdasarkan indikator akuntabilitas (Mahmudi,2015:9-11)

1. Akuntabilitas hukum dan kejujuran

2. Akuntabilitas manajerial

3. Akuntabilitas program

4. Akuntabilitas kebijakan

5. Akuntabilitas finansial

\section{Dokumen}

Studi dokumen merupakan pelengkap dari penggunaan metode observasi dan wawancara dalam penelitian kualitatif. Hasil penelitian dari wawancara, akan lebih kredibel atau dapat dipercaya kalau didukung oleh sejarah pribadi kehidupan di masa kecil, di sekolah, di tempat kerja, di masyarakat, dan autobiografi. Dokumen bisa berbentuk tulisan, gambar, atau karya-karya monumental dari seseorang.

\section{Teknik Analisis Data}

\section{Reduksi Data}

Mereduksi data berarti merangkum, memilih hal-hal yang pokok, memfokuskan pada hal-hal yang penting, dicari tema dan polanya. Data yang diperoleh dari lapangan jumlahnya cukup banyak, untuk itu maka perlu dicatat secara teliti dan rinci. Semakin lama peneliti ke lapangan, maka jumlah data akan semakin banyak, kompleks dan rumit. Untuk itu perlu segera dilakukan analisis data melalui reduksi data. Reduksi data diartikan sebagai proses pemilihan, pemisahan, perhatian pada penyederhanaan, pengabstrakan dan transformasi data kasar yang muncul dari catatan-catatan tertulis lapangan. 


\section{Triangulasi}

Selain menggunakan reduksi data peneliti juga menggunakan teknik Triangulasi sebagai teknik untuk mengecek keabsahan data. Dimana dalam pengertiannya triangulasi adalah teknik pemeriksaan keabsahan data yang memanfaatkan sesuatu yang lain dalam membandingkan hasil wawancara terhadap objek penelitian. Triangulasi yang digunakan peneliti yaitu triangulasi dengan sumber. Triangulasi dengan sumber artinya membandingkan dan mengecek balik derajat kepercayaan suatu informasi yang diperoleh melalui waktu dan alat yang berbeda dalam penelitian kualitatif, Adapun untuk mencapai kepercayaan itu maka ditempuh dengan Membandingkan data hasil pengamatan dengan data hasil wawancara dan Membandingkan hasil wawancara dengan isi suatu dokumen yang berkaitan.

\section{Penyajian Data}

Pada penelitian ini penyajian data dilakukan dalam bentuk uraian, bagan, hubungan antar kategori dan sejenisnya, dan menyajikan data dalam bentuk teks yang bersifat naratif.

\section{Penarikan Kesimpulan}

Penarikan kesimpulan dilakukan dengan pengambilan intisari dari rangkaian kategori hasil penelitian berdasarkan studi pustaka, wawancara serta dokumentasi hasil penelitian.

\section{Alat Analisis}

1. Analisis berdasarkan Permendagri Nomor 113 Tahun 2014 tentang pengelolaan keuangan desa yang meliputi: Pelaksanaan, Pelaporan, Dan Pertangggungjawaban. Serta Pelaksana Teknis Pengelolaan Keuangan Desa yang selanjutnya disingkat PTPKD adalah unsur perangkat desa yang membantu Kepala Desa untuk melaksanakan pengelolaan keuangan desa yang terdiri dari:

1) Sekretaris Desa, bertindak selaku koordinator pelaksanaan pengelolaan keuangan desa.

2) Kepala Seksi adalah unsur dari pelaksana teknis kegiatan dengan bidangnya.

3) Bendahara adalah unsur staf sekretariat desa yang membidangi urusan administrasi keuangan untuk menatausahakan keuangan desa.

2. Analisis berdasarkan Indikator Akuntabilitas (Mahmudi,2015:9-11) yang meliputi:

1) Akuntabilitas hukum dan kejujuran

2) Akuntabilitas manajerial

3) Akuntabilitas program

4) Akuntabilitas kebijakan

5) Akuntabilitas finansial

\section{HASIL PENELITIAN DAN PEMBAHASAN}

Peran Perangkat Desa Dalam Pengelolaan Dana Desa Di Desa Batu Raya I Kecamatan Gunung Timang

Peran perangkat desa dalam pengelolaan dana desa di Desa Batu Raya I sesuai dengan hasil wawancara yang dilakukan di kantor desa adalah sebagai berikut: 


\section{a. Pelaksanaan}

Dalam tahap Pelaksanaan Pengelolaan Dana Desa di Desa Batu Raya I, perangkat desa ikut berperan dalam pelaksanaan pengelolaan dana desa karena perangkat desa sebagai pelaksana kegiatan sesuai bidangnya. Perangkat desa semua berperan sesuai bidangnya masing-masing seperti sekretaris sebagai pelaksana teknis di bantu dengan kaur sesuai bidangnya misalnya dalam hal keuangan di bantu oleh kaur keuangan, dalam hal pembangunan ada kaur pembangunan sebagai orang yang memimpin terlaksananya pembangunan program dari Dana Desa, dan untuk urusan administrasi keuangan sekretaris desa dibantu oleh bendahara. Seperti yang di sampaikan Kepala Desa Batu Raya I Bapak Sehat:

"Iya perangkat desa ikut berperan, karena yang di utamakan adalah perangkat desa sebagai pengelola kegiatan."(Wawancara, 30 April 2018 Pukul 07:58 WIB di Kantor Desa)

Bapak Agus Susilo sebagai Sekreratis Desa menyampaikan:

"Tkut berperan, karena perangkat desa dibentuk sebagai pengelola kegiatan dalam pengelolaan dana desa." (Wawancara, 18 April 2018 Pukul 09:53 WIB)

Ditambahkan oleh saudari Tati Sandari selaku Kaur Keuangan:

"Iya perangkat desa ikut berperan, karena sesuai ketentuan dan soalnya emang yang berperan penting itu perangkat desa" (Wawancara, 19 april 2018 pukul 09:15 WIB)

Bapak Sugeng Hardja selaku Kaur Pembangunan mengatakan:

"Iya jelas itu berperan. Semua berperan tidak hanya saya selaku kaur pembangunan."(wawancara, 19 April 2018 Pukul 07:40 WIB)

Saudari debi malasari sebagai Bendahara menyampaikan bahwa:

"Iya berperan karena perangkat desa sebagai pengelola kegiatan." (Jum'at, 20 April 2018 Pukul 08:09 WIB)

Dalam tahap pelaksanaan pengelolaan dana desa perangkat desa sudah berperan, hal tersebut dapat dibuktikan dengan adanya kaur keuangan sebagai pelaksana kegiatan di bidang keuangan, kaur pembangunan sebagai pelaksana kegiatan di bidang pembangunan, dan kaur lain sebagai pengelola atau pelaksana kegiatan sesuai dengan bidangnya seperti kaur umum, kaur pemerintahan, kaur kesos, serta bendahara sebagai pelaksana kegiatan administrasi keuangan desa.

\section{b. Pelaporan}

Dalam tahap Pelaporan Pengelolaan Dana Desa di Desa Batu Raya I perangkat desa sebagai tim PTPKD ikut berperan dalam menyusun laporan realisasi APBDes dan laporan penyelenggaraan pemerintahan, seperti yang di sampaikan Kepala Desa Batu Raya I Bapak Sehat:

"Yang ikut berperan itu saya sendiri sebagai kepala desa, sekretaris desa, bendahara, dan perangkat yang ada yang memiliki peran masing-masing." (Senin, 30 April 2018 Pukul 07:58 WIB).

Bapak Agus Susilo sebagai Sekreratis Desa menyampaikan:

"Yang ikut berperan itu kepala desa dan PTPKD, yaitu pelaksana teknis pengelolaan keuangan desa yang terdiri dari sekretaris desa, kepala seksi, dan bendahara."(rabu, 18 April 2018 Pukul 09:53 WIB. 
Di tambahkan oleh saudari Tati Sandari selaku Kaur Keuangan:

"Yang ikut berperan itu kepala desa, sekretaris desa, kaur keuangan dan bendahara desa." (Kamis, 19 april 2018 pukul 09:15 WIB).

Bapak Sugeng Hardja selaku Kaur Pembangunan mengatakan:

"Yang ikut berperan itu kepala desa, sekretaris desa, kaur keuangan dan bendahara desa."(Kamis, 19 April 2018 Pukul 07:40 WIB).

Saudari debi malasari sebagai Bendahara menyampaikan bahwa:

"Yang ikut berperan itu kepala desa, PTPKD. Dan kepala desa yang melaporkan kepada bupati sebagai penanggung jawab." (Jum'at, 20 April 2018 Pukul 08:09 WIB).

Dalam tahap pelaporan pengelolaan dana desa perangkat desa sudah berperan dalam penyusunan laporan realisasi APBDes dan laporan penyelenggaraan pemerintahan, sementara yang menyampaikannya kepada Bupati Barito Utara adalah kepala desa. hal tersebut dibuktikan dengan adanya perangkat desa sebagai pelaksana kegiatan sesuai bidangnya, sehingga dalam penyusunan laporan realisasi APBDes harus ada perangkat desa sebagai orang yang melaksanakan kegiatan sesuai bidangnya. Dan kepala desa menyampaikan laporan realisasi APBDes dan laporan penyelenggaraan pemerintahan Kepada Bupati Barito Utara.

\section{c. Pertanggungjawaban}

Dalam tahap Pertanggungjawaban Pengelolaan Dana Desa di Desa Batu Raya I, perangkat desa membentuk tim untuk bekerja sama dan bertanggung jawab atas pengelolaan dana desa sesuai rencana yang telah ditetapkan, seperti yang di sampaikan Kepala Desa Batu Raya I Bapak Sehat:

"Tanggung jawab bersama, apa yang sudah dikerjakan merupakan peran perangkat desa karena semua masuk dalam tim." (Senin, 30 April 2018 Pukul 07:58 WIB).

Bapak Agus Susilo sebagai Sekreratis Desa menyampaikan:

"Untuk pertanggungjawaban berorientasi pada visi dan misi desa sesuai dengan RAP yang ada. Karena pada intinya dana desa merupakan amanah dari pemerintah pusat kepada pemerintah desa." (kamis, 18 April 2018 Pukul 09:53 WIB).

Di tambahkan oleh saudari Tati Sandari selaku Kaur Keuangan:

"Apa yang sudah terencana harus tercapai harus terealisasi, kalau sudah harus ada laporannya." (Kamis, 19 april 2018 pukul 09:15 WIB).

Bapak Sugeng Hardja selaku Kaur Pembangunan mengatakan:

"Kalau sudah menyusun rencana lalu melaksanakan pembangunan sesuai RAB dan bentuk pembangunan dana harus disesuaikan RAB."(Kamis, 19 April 2018 Pukul 07:40 WIB).

Saudari debi malasari sebagai Bendahara menyampaikan bahwa:

"Dikelola semaksimal mungkin." (Jum'at, 20 April 2018 Pukul 08:09 WIB).

Dalam tahap pertanggungjawaban pengelolaan dana desa perangkat desa berprinsip bahwa dalam pengelolaan dana desa, apa yang sudah terencana harus tercapai. Hal tersebut dibuktikan dengan terlaksananya pembangunan di desa sesuai rencana yang telah di tetapkan sebelumnya seperti pembangunan balai pertemuan, kantor BPD, balai desa, siring parit dan perbaikan jalan gang. 


\section{Akuntabilitas Pengelolaan Dana Desa Di Desa Batu Raya I Kecamatan Gunung Timang}

Menurut Setiyono (2014: 193) Akuntabilitas adalah prinsip yang menekankan bahwa segala perilaku, kebijakan, dan kegiatan institusi publik selalu dapat dipertanggungjawabkan dalam kerangka kepentingan publik. Tidak boleh ada sedikitpun fasilitas, anggaran, dan kewenangan yang dimiliki, digunakan bagi sesuatu yang bertujuan untuk kepentingan pribadi maupun kelompok.

Penggunaan Dana Desa (DD) yang di terima Desa Batu Raya I digunakan untuk pembiayaan pelaksanaan pembangunan desa dan pemberdayaan masyarakat. Pelaksanaan pembangunan desa meliputi pembangunan jalan desa, pembangunan sarana dan prasarana fisik sosial, serta pembangunan sarana dan prasarana pendidikan. Sedangkan untuk biaya pemberdayaan masyarakat meliputi kegiatan pemberdayaan poelayanan pendidikan dan kebudayaan.

\section{a. Pelaksanaan}

Dalam Pelaksanaan Pengelolaan Dana Desa (DD) di Desa Batu Raya I sudah cukup baik dan sesuai dengan peraturan pemerintah. Semua penerimaan dan pengeluaran desa dalam rangka pelaksanaan kewenangan desa dilaksanakan melalui rekening kas desa. Semua kegiatan menggunakan buku pembantu kas kegiatan dan semua kegiatan disertai dengan Rencana Anggaran Biaya. Rencana Anggaran Biaya di verifikasi oleh sekretaris desa dan di sahkan oleh kepala desa.

Dan Sesuai dengan hasil wawancara yang dilakukan di Kantor Desa Batu Raya I mengungkapkan bahwa:

"Kinerja perangkat desa baik sesuai peraturan pemerintah, mereka bekerja sama karena setiap bidang memiliki tugas masing-masing." (Kepala Desa Senin 30 April 2018 Pukul 07:58 WIB)

Dan pernyataan berikut:

"Dana desa yang diperoleh sudah ada instrumen untuk pengelolaannya. dan dalam mengelola dana desa, dana itu digunakan untuk pembangunan dan mensosialisasikan dengan masyarakat. Perangkat desa mensosialisasikan tujuan dari dana desa yaitu untuk pembangunan desa."(Sekreratis Desa Rabu 18 April 2018 Pukul 09:53 WIB)

Dipertegas dengan penjelasan sebagai berikut:

"Menyusun mulai RAPBDes, APBDes, dan sampai peng SPJ an. Kita juga melakukan pengendalian dalam melaksanakan kegiatan karena APBDes merupakan acuan dalam kegiatan dan memverifikasi nota-nota dalam pengSPJ an. Kenapa harus diverivikasi karena harus bayar pajak. Karena toko disini rata-rata tidak memiliki NPWP sehingga dikenakan pajak 13\%. Sekretaris memverifikasi, kalau tidak sesuai dikenakan denda."(Sekreratis Desa Rabu 18 April 2018 Pukul 09:53 WIB)

Dan pernyataan berikut:

"Kalau di bangunan ada RAB dan sudah ada aplikasi jadi gak bisa melenceng, harus sesuai RAB yang ditetapkan."(Kaur Pembangunan Kamis 19 April 2018 Pukul 07:40 WIB)

Dalam tahap Pelaksanaan Pengelolaan Dana Desa yang dilakukan oleh pemerintah Desa Batu Raya I, pelaksanaannya sudah cukup baik dan sesuai dengan peraturan pemerintah. Semua penerimaan dan pengeluaran dilaksanakan melalui 
rekening kas desa. Dalam melaksanakan kegiatan, APBDes dijadikan acuan dan pemerintah desa Batu Raya I melakukan pengendalian dalam melaksanakan kegiatan dengan menggunakan buku kas pembantu kegiatan. Semua kegiatan yang dilakukan di sertai dengan Rencana Anggaran Biaya. Rencana Anggaran Biaya di verifikasi oleh Sekretaris Desa dan di sahkan oleh Kepala Desa.

\section{b. Pelaporan}

Di Desa Batu Raya I dalam tahap pelaporan pengelolaan keuangan desa sudah sesuai dengan Permendagri Nomor 113 Tahun 2014. Kepala desa menyampaikan laporan realisasi APBDesa kepada Bupati/Walikota berupa Laporan semester pertama berupa laporan realisasi APBDesa, dan Laporan semester akhir tahun. Tetapi dalam menyampaikan laporan realisasi APBDesa dan laporan penyelenggaraan pemerintah desa pernah mengalami keterlambatan. Keterlambatan itu karena waktu,situasi dan kondisi, akses terutama akses jalan menuju kecamatan atau kabupaten yang masih ada kerusakan jalan terutama jika musim hujan sehingga bisa menghambat kepala desa dalam menyampaikan laporan realisasi APBDes kepada bupati, dan kendala SDM yang belum memadai di Desa Batu Raya I.

Tabel 4.5

Laporan Realisasi Pelaksanaan

Anggaran Pendapatan Dan Belanja Desa (APBDes)

Pemerintah Desa Batu Raya I

Tahun Anggaran 2017

\begin{tabular}{|l|c|c|c|}
\hline $\begin{array}{l}\text { KODE } \\
\text { REK. }\end{array}$ & URAIAN & $\begin{array}{c}\text { ANGGARAN } \\
(\mathrm{Rp})\end{array}$ & KET \\
\hline \multicolumn{1}{|c|}{2} & \multicolumn{1}{|c|}{3} & 4 \\
\hline $\mathbf{1}$ & PENDAPATAN & & \\
\hline 1.1 & Pendapatan Asli Desa & $\mathbf{9 . 6 0 0 . 0 0 0}$ & $100 \%$ \\
\hline 1.1 .1 & Hasil Usaha Desa & 9.600 .000 & $100 \%$ \\
\hline 1.2 & Pendapatan Transfer & $\mathbf{1 . 4 3 1 . 4 7 4 . 0 8 9}$ & $100 \%$ \\
\hline 1.2 .1 & Dana Desa & 816.000 .000 & $100 \%$ \\
\hline 1.2 .2 & $\begin{array}{l}\text { Bagi Hasil Pajak Dan } \\
\text { Retribusi }\end{array}$ & 18.198 .189 & $100 \%$ \\
\hline 1.2 .3 & Alokasi Dana Desa & 597.275 .900 & $100 \%$ \\
\hline & JUMLAH PENDAPATAN & $\mathbf{1 . 4 4 1 . 0 7 4 . 0 8 9}$ & $100 \%$ \\
\hline $\mathbf{2}$ & BELANJA & & \\
\hline 2.1 & Belanja Desa & $\mathbf{1 . 3 4 1 . 0 7 4 . 0 8 9}$ & $100 \%$ \\
\hline 2.1 .1 & Belanja Pegawai & 308.750 .000 & $100 \%$ \\
\hline
\end{tabular}




\begin{tabular}{|l|c|r|c|}
\hline 2.1 .2 & Belanja Barang Dan Jasa & 395.541 .482 & $100 \%$ \\
\hline 2.1 .3 & Belanja Modal & 636.782 .607 & $100 \%$ \\
\hline & JUMLAH BELANJA & $\mathbf{1 . 3 4 1 . 0 7 4 . 0 8 9}$ & $100 \%$ \\
\hline & SURPLUS/(DEFISIT) & $\mathbf{1 0 0 . 0 0 0 . 0 0 0}$ & $100 \%$ \\
\hline $\mathbf{3}$ & PEMBIAYAAN & & \\
\hline $\mathbf{3 . 2}$ & Pengeluaran pembiayaan & $\mathbf{1 0 0 . 0 0 0 . 0 0 0}$ & $100 \%$ \\
\hline $\mathbf{3 . 2 . 2}$ & Penyertaan modal desa & $\mathbf{1 0 0 . 0 0 0 . 0 0 0}$ & $100 \%$ \\
\hline
\end{tabular}

Sunber: Surat Pertanggungjawaban Semester I, data diolah

Dalam Pelaporan Pengelolaan Dana Desa (DD) di Desa Batu Raya I sesuai dengan hasil wawancara yang dilakukan di Kantor Desa Batu Raya I mengungkapkan bahwa dalam menyampaikan laporan realisasi APBDesa dan laporan penyelenggaraan pemerintah desa pernah mengalami keterlambatan, sesuai dengan pernyataan berikut: "Kadang pernah, karena waktu, situasi dan kondisi. Semua desa sama jarang yang tepat waktu." (Kepala Desa Senin 30 April 2018 Pukul 07:58 WIB)

Dipertegas dengan penjelasan berikut:

"Pernah, karena akses dan kendala SDM. Apalagi baru menggunakan siskeudes, karena siskeudes yang baru dan pelatihan baru di ikuti sehingga belum dapat dilaksanakan karena keterbatasan SDM. Kami mengakui keterlambatan karena memang keadaannya seperti itu."(Sekreratis Desa Rabu 18 April 2018 Pukul 09:53 WIB)

Dalam tahap pelaporan pengelolaan dana desa di Desa Batu Raya I yang dilakukan oleh pemerintah desa sudah sesuai dengan Permendagri Nomor 113 Tahun 2014. Kepala Desa Batu Raya I menyampaikan laporan realisasi APBDesa kepada Bupati/Walikota berupa Laporan semester pertama berupa laporan realisasi APBDesa, dan Laporan semester akhir tahun. Tetapi dalam menyampaikan laporan realisasi APBDesa dan laporan penyelenggaraan pemerintah desa pernah mengalami keterlambatan. Keterlambatan itu karena waktu,situasi dan kondisi, serta akses di Desa Batu Raya I yang kurang memadai. Kendala SDM yang belum memadai juga menjadi penyebab keterlambatan dalam penyampaian pelaporan karena jika SDM belum memadai tentu akan mengalami kesulitan dalam menyusun laporan realisasi pelaksanaan APBDes sesuai dengan aturan pemerintah sehingga kepala desa pun terlambat menyampaikannya kepada Bupati Barito Utara. 


\section{c. Pertanggungjawaban}

Dalam Pertanggungjawaban Pengelolaan Dana Desa (DD) di Desa Batu Raya I sudah sesuai dengan Permendagri Nomor 113 Tahun 2014 Kepala desa menyampaikan laporan pertanggungjawaban realisasi pelaksanaan APBDesa kepada Bupati/Walikota melalui camat setiap akhir tahun anggaran. Laporan pertanggungjawaban pelaksanaan realisasi pelaksanaan APBDesa terdiri dari pendapatan, belanja, dan pembiayaan. Laporan di tetapkan peraturan desa dan dilampiri:

1) Format Laporan Pertanggungjawaban Realisasi Pelaksanaan APBDes Tahun Anggaran berkenaan.

2) Format Laporan Kekayaan Milik Desa Per 31 Desember Tahun Anggaran berkenaan.

3) Format Laporan Program Pemerintah Dan Pemerintah Daerah yang masuk ke desa.

Dan sesuai dengan hasil wawancara yang dilakukan di Kantor Desa Batu Raya I mengungkapkan bahwa Laporan Realisasi Pelaksanaan APBDesa disampaikan tepat waktu yaitu setiap akhir tahun anggaran, sesuai dengan pernyataan berikut:

"Realisasi tepat waktu karena itu realisasi harus tepat waktu yang lambat itu LPJ nya."(Kepala Desa Senin 30 April 2018 Pukul 07:58 WIB)

Dipertegas dengan penjelasan berikut:

"Tepat waktu, karena harus disampaikan akhir tahun. Laporan realisasi yang manual duluan karena untuk tahap 2 harus ada laporan realisasi dulu." (Sekreratis Desa Rabu 18 April 2018 Pukul 09:53 WIB)

Dan pernyataan berikut:

"Iya disampaikan Tepat waktu, karena laporan realisasi pelaksanaan APBDes itu adalah syarat agar dana bisa keluar."(Kaur Keuangan Kamis 19 April 2018 pukul 09:15 WIB)

Dalam tahap pertanggungjawaban pengelolaan dana desa yang dilakukan oleh pemerintah Desa Batu Raya I sudah sesuai dengan Permendagri Nomor 113 Tahun 2014. Kepala Desa Batu Raya I menyampaikan laporan pertanggungjawaban realisasi pelaksanaan APBDesa kepada Bupati/Walikota melalui camat setiap akhir tahun anggaran. Laporan pertanggungjawaban pelaksanaan realisasi pelaksanaan APBDesa yang dibuat oleh pemerintah desa Batu Raya I terdiri dari pendapatan, belanja, dan pembiayaan. Laporan realisasi pelaksanaan APBDes disampaikan tepat waktu yaitu setiap akhir tahun anggaran, karena laporan tersebut merupakan syarat agar dana berikutnya dari pemerintah dapat diterima.

\section{Indikator Kesesuaian Akuntabilitas Terhadap Kepala Desa Dan Perangkat Desa Batu Raya I}

\section{Akuntabilitas Hukum Dan Kejujuran}

Pemerintah Desa Batu Raya I sudah patuh terhadap peraturan yang berlaku dan bersikap jujur, Semua kegiatan yang berkaitan dengan keuangan desa dilakukan berdasarkan peraturan yang telah di tetapkan dan kegiatan yang dilakukan adalah berdasarkan hasil musyawarah desa, setiap dana yang masuk akan di beritahukan seluruh kegiatannya. Dan pemerintah desa telah membuat Baliho APBDes sesuai dengan aturan pemerintah yang mengharuskan pemerintah desa membuat baliho 
APBDes agar masyarakat dapat mengetahui dengan jelas berapa jumlah anggaran yang diperoleh dan digunakan untuk apa saja. Sesuai dengan pernyataan berikut:

"Sudah menjalankan apa yang telah diatur dalam Permendagri nomor 113 tahun 2014, karena semua pedomannya itu."(Kepala Desa Senin 30 April 2018 Pukul 07:58 WIB)

Dipertegas dengan penjelasan berikut:

"Sudah menjalankan apa yang telah diatur dalam Permendagri nomor 113 tahun 2014. Karena kalau tidak sesuai ditolak atau disuruh memperbaiki karena itu memang acuannya, dan kalau ada kekurangan harus melengkapi dulu."(Sekreratis Desa Rabu 18 April 2018 Pukul 09:53 WIB)

Dan pernyataan berikut:

"Pemerintah sudah menyarankan membuat laporan seperti baliho berapa jumlah dana yang sudah dilaksanakan,papan informasi agar masyarakat tau apa saja yang sudah dijalankan terkait penggunaan dana desa."(Kepala Desa Senin 30 April 2018 Pukul 07:58 WIB)

\section{Akuntabilitas Manajerial}

Pemerintah desa sudah melakukan pengelolaan organisasi secara efisisen dan efektif. Pemerintah Desa sudah melaksanakan tugas dan fungsinya dengan baik. Prosedur dalam Dana Desa perlu adanya sebuah Tim dalam pelaksanaanya, dan di Desa Batu Raya I pemerintah desa dalam mengelola dana desa sudah membentuk tim sesuai peraturan pemerintah dan ketentuan yang berlaku,tim tersebut yaitu kepala desa yang dibantu oleh perangkat desa yang terdiri dari sekretaris desa, pelaksana teknis sesuai bidangnya seperti kaur keuangan, kaur pembangunan dan kaur lainnya, serta bendahara desa. sesuai dengan pernyataan berikut:

"Dibentuk berdasarkan peraturan pemerintah, kami membuat tim lalu dibuat Sk keputusan oleh saya selaku kepala desa."(Kepala Desa Senin 30 April 2018 Pukul 07:58 WIB)

Dipertegas dengan penjelasan berikut:

"Karena kepala desa pemegang kekuasaan maka kepala desa menunjuk atau di SK kan. Kepala desa membentuk tim berdasarkan Permendagri Nomor 113 Tahun 2014."(Sekreratis Desa Rabu 18 April 2018 Pukul 09:53 WIB)

Dan dalam pengelolaan dana desa,pemerintah desa menjalankan mekanisme pengelolaan dana desa seperti yang di sampaikan Kepala Desa Batu Raya I Bapak Sehat: "Mekanisme berdasarkan aturan pemerintah tidak bisa melanggar karena itu acuan desa untuk melakukan kegiatan semuanya pedomannya pada peraturan pemerintah."(Senin 30 April 2018 Pukul 07:58 WIB)

Dan Bapak Agus Susilo Sebagai Sekretaris Desa menambahkan:

"Mulai dari menyusun perencanaan, dalam perencanaan itu ada musyawarah perencanaan,membuat rancangan perencanaan dan menyusun RAPBDes. Rancangan di teliti untuk di posting, setelah posting di aplikasi APBDes baru bisa di cairkan dan kepala desa langsung membuat APBDes."(Rabu 18 April 2018 Pukul 09:53 WIB)

\section{Akuntabilitas Program}

Program yang sudah berjalan terkait tujuan yang telah ditetapkan di Desa Batu Raya I sudah tercapai, hal tersebut dapat dibuktikan dengan berdirinya balai pertemuan, 
kantor BPD, perbaikan jalan dan siring parit. Program tersebut memberikan hasil yang optimal karena dengan adanya pembangunan balai pertemuan dan kantor BPD dapat menghindari adanya tumpang tindih penggunaan bangunan gedung, dan dengan adanya siring parit yang dibuat banjir yang sering terjadi dapat teratasi.

Dalam penyusunan program rencana penggunaan dana desa di Desa Batu Raya I melibatkan pihak yang terkait seperti perangkat desa, BPD, lembaga yang ada di desa dan tokoh masyarakat, sesuai dengan pernyataan berikut:

"Semua terlibat, termasuk masyarakat,BPD,perangkat desa, semua musyawarah. Dalam musyawarah kami merencanakan program apa saja yang akan dilaksanakan."(Kepala Desa Senin 30 April 2018 Pukul 07:58 WIB)

Dipertegas dengan penjelasan berikut:

"Yang dilibatkan kepala desa, BPD, kelembagaan yang ada di desa, perangkat desa, tokoh masyarakat, tokoh agama."(Sekreratis Desa Rabu 18 April 2018 Pukul 09:53 WIB)

Dan pernyataan berikut:

"Perangkat desa, masyarakat, lembaga-lembaga yang ada di desa, BPD. Karena masyarakat harus tau besaran dan penggunaan untuk apa saja." (Kaur Keuangan Kamis 19 april 2018 pukul 09:15 WIB)

Dan mengenai program yang sudah berjalan terkait dengan rencana penggunaan dana desa sudah berjalan dengan baik. Hal tersebut dapat dibuktikan dengan terlaksananya program pembangunan seperti Pembangunan Balai Desa, Balai Pertemuan, Gedung BPD, Perpustakaan Desa, Siring Parit, Dan Perbaikan Jalan Gang. Sesuai dengan pernyataan berikut:

"Program yang sudah berjalan sesuai dengan hasil musyawarah dan kemampuan keuangan yang ada, program sudah berjalan dengan baik."(Kepala Desa Senin 30 April 2018 Pukul 07:58 WIB)

Dipertegas dengan penjelasan berikut:

"Program yang sudah berjalan sesuai dengan APBDes dan alhamdulillah tidak ada hambatan, tapi ada kendala ketersediaan material."(Sekreratis Desa Rabu 18 April 2018 Pukul 09:53 WIB)

Dan pernyataan berikut:

"Program berjalan lancar, walau ada hambatan tetapi dapat terlaksana dengan baik." (Kaur Keuangan Kamis 19 april 2018 pukul 09:15 WIB)

\section{Akuntabilitas Kebijakan}

Pertanggungjawaban pemerintah desa atas kebijakan-kebijakan yang telah di ambil terhadap masyarakat terutama dalam melaksanakan prinsip akuntabilitas dalam mengelola dana desa dilihat dengan adanya keterbukaan mengenai penggunaan dana desa dan realisasi seluruh dana yang diterima desa dengan adanya papan informasi tentang pelaksanaan pembangunan, forum musyawarah, dan baliho APBDes. Sesuai dengan pernyataan berikut:

"Di sampaikan lewat forum musyawarah kepada masyarakat dan baliho APBDes, karena dari BPK itu harus disampaikan dengan papan informasi dan baliho." (Kepala Desa Senin 30 April 2018 Pukul 07:58 WIB) 
Dipertegas dengan penjelasan berikut:

"Setelah tersusun dalam APBDes, tim pelaksana lebih condong ke fisik karena itu yang akan disampaikan melalui papan informasi tentang pelaksanaan pembangunan. Dan informasi disampaikan dengan baliho APBDes karena dari BPK seperti itu."(Sekreratis Desa Rabu 18 April 2018 Pukul 09:53 WIB)

Dan pernyataan berikut:

"Pemerintah sudah menyarankan membuat laporan seperti baliho berapa jumlah dana yang sudah dilaksanakan,papan informasi agar masyarakat tau apa saja yang sudah dijalankan terkait penggunaan dana desa." (Kaur Keuangan Kamis 19 april 2018 pukul 09:15 WIB)

\section{Akuntabilitas Finansial}

Pertanggungjawaban pemerintah desa atas penggunaan uang publik terhadap masyarakat terutama dalam melaksanakan prinsip akuntabilitas dalam mengelola dana desa dilihat dengan adanya keterbukaan mengenai penggunaan dana karena dalam menggunakan dana desa pemerintah desa menyusun program terkait dengan penggunaan dana desa berdasarkan hasil musyawarah bersama yang melibatkan lembaga yang ada di desa serta masyarakat. Keterbukaan mengenai penggunaan dana dan realisasi seluruh dana yang diterima desa dapat juga dilihat dengan adanya papan informasi tentang pelaksanaan pembangunan, forum musyawarah, dan baliho APBDes. Sesuai dengan pernyataan berikut:

"Lewat rapat bersama dan baliho APBDes, misal jalan anggaran sekian, gorong-gorong sekian, lewat papan informasi."(Kepala Desa Senin 30 April 2018 Pukul 07:58 WIB)

Dipertegas dengan penjelasan berikut:

"Rapat masyarakat dan lembaga kita undang, disampaikan secara rinci tentang dana desa, menyampaikan jenis proyek dan anggarannya berapa, baliho APBDes."(Sekreratis Desa Rabu 18 April 2018 Pukul 09:53 WIB)

Dalam penyelenggaraan pemerintahan, dana desa digunakan untuk bidang pembangunan dan pemberdayaan sesuai dengan pernyataan berikut:

"Balai pertemuan, gedung BPD, bidang pemberdayaan yaitu pelatihan PKK dan pendataan."(Kepala Desa Senin 30 April 2018 Pukul 07:58 WIB)

Dipertegas dengan penjelasan berikut:

"Balai pertemuan, gedung BPD, balai adat, pemberdayaan pelaksana kader posyandu dan PKK, penyelesaian balai desa."(Sekreratis Desa Rabu 18 April 2018 Pukul 09:53 WIB)

\section{KESIMPULAN, IMPLIKASI DAN KETERBATASAN PENELITIAN}

Perangkat Desa sudah berperan dalam pengelolaan dana desa dan pelaksanaan, pelaporan, dan pertanggungjawaban Tetapi yang banyak berperan hanya sekretaris desa dan kepala desa karena masih kurangnya pengetahuan perangkat desa lainnya tentang pengelolaan dana desa. Sehingga diperlukan adanya pembinaan lebih lanjut karena belum sepenuhnya sesuai dengan ketentuan perundang-undangan. Mengenai Akuntabilitas Perangkat Desa dalam pengelolaan dana desa di Desa Batu Raya I yang di ukur melalui lima indikator yang menentukan dapat dikatakan terlaksana dengan baik secara keseluruhan. 
Temuan pada penelitian ini yaitu Perangkat Desa sudah berperan dalam pengelolaan dana desa Tetapi yang banyak berperan hanya sekretaris desa dan kepala desa karena masih kurangnya pengetahuan perangkat desa lainnya tentang pengelolaan dana desa.

Salah satu keterbatasan pada penelitian ini yaitu kurangnya pembahasan secara detail dan mendalam karena penelitian ini hanya membahas pengelolaan dana desa yang meliputi pelaksanaan, pelaporan, dan pertanggungjawaban. Sehingga saran untuk peneliti selanjutnya agar dapat membahas secara lebih detail.

\section{DAFTAR PUSTAKA}

Arie Rekza Cahya. 2016. Profesionalitas Dan Akuntabilitas Aparatur Desa Dalam Pelaksanaan Alokasi Dana Desa. Skripsi. Lampung Tengah.

Bastian, Indra.2006. Akuntansi SektorPublik; Suatu Pengantar. Jakarta: Erlangga.

Departemen Pendidikan dan Kebudayaan. 1999. Kamus Besar Bahasa Indonesia, edisi kedua. Jakarta: Balai Pustaka.

Firdaus, M Aziz. 2012. Metode Penelitian. Tangerang: Jelajah Nusa.

Hamzah, Ardi. 2015. Tata Kelola Pemerintahan Desa Menuju Desa Mandiri, Sejahtera, dan Partisipatoris. Penerbit Pustaka Jawa Timur.

Husaini, Purnomo.2009.Metode Penelitian Kualitatif. Jakarta: Salemba Empat.

Irma Ade. 2015. Akuntabilitas Pengelolaan Alokasi Dana Desa (ADD) Dikecamatan Dolo Selatan Kabupaten Sigi. Jurnal Penelitian. Palu: Sulawesi Tengah.

Kementerian Keuangan Republik Indonesia. 2015. Kebijakan Umum Dana Desa (Berdasarkan UU No.6 Tahun 2014 dan PP No.60 Tahun 2014).

Mahsun, Mohamad. 2006. Pengukuran Kinerja Sektor Publik. Yogyakarta: BPFE.

Moleong, Lexy J. 2005. Metode Penelitian Kualitatif. Bandung: PT. Remaja Rosdakarya.

Mahmudi. 2011. Akuntansi Sektor Publik. Yogyakarta: UII Pres

Mardiasmo. 2010. Akuntansi Sektor Publik. Yogyakarta: CV. ANDI OFFSET.

Ndraha. 1991. Pemerintahan Desa. Jakarta: PT. Raja Grafindo Persada.

Nordiawan, Deddi. 2006. Akuntansi Sektor Publik. Jakarta: Salemba Empat.

Permendagri Nomor 113 Tahun 2014 Tentang Pengelolaan Keuangan Desa. 
Renyowijoyo, Muindro. 2008. Akuntansi Sektor Publik; Organisasi Non Laba. Jakarta:

Mitra Wacana Media.

Setiyono, Budi. 2014. Pemerintahan dan Manajemen Sektor Publik. Yogyakarta:

CAPS (Center of Academic Publishing Service).

Sugiyono. 2009. Metode Penelitian Kuantitatif Kualitatif dan RङDD. Bandung:

C.V. Alfabeta.

Sujarweni, V. Wiratna. 2015. Akuntansi Sektor Publik: Teori, Konsep, dan Aplikasi. Yogyakarta: Pustaka Baru.

Sunardjo.1984. Pemerintahan Desa dan Administrasi Desa. Bandung: PT. Remaja Rosdakarya.

Tri Indrianasari Neny. 2017. Peran Perangkat Desa Dalam Akuntanbilitas Pengelolaan Keuangan Desa (Studi Pada Desa Karangsari Kecamatan Sukodono). Jurnal penelitian. Lumajang: STIE Widya Gama Lumajang.

Undang-Undang No.6 Tahun 2014 tentang Desa.

Waluyo. 2007. Manajemen Publik (Konsep, Aplikasi dan Implementasinya Dalam Pelaksanaan Otonomi Daerah). Bandung: Penerbit Mandar Maju.

Widjaja, H.A.W. 2002. Pemerintahan Desa dan Administrasi Desa. Jakarta: PT. Raja Grafindo Persada.

Yuliansyah, Rusmianto.2016. Akuntansi Desa. Jakarta: Salemba Empat.

\section{APENDIKS \\ HASIL KEGIATAN WAWANCARA \\ Akuntabilitas Pengelolaan Keuangan Desa \\ Pelaksanaan}

1. Apakah Perangkat Desa berperan dalam pelaksanaan pengelolaan dana desa? Jawaban:

Kepala Desa (Senin, 30 April 2018 Pukul 07:58 WIB)

Iya perangkat desa ikut berperan, karena yang di utamakan adalah perangkat desa sebagai pengelola kegiatan. 
Sekreratis Desa (Rabu, 18 April 2018 Pukul 09:53 WIB)

Ikut berperan, karena perangkat desa dibentuk sebagai pengelola kegiatan dalam pengelolaan dana desa.

Kaur Keuangan (Kamis, 19 april 2018 pukul 09:15 WIB)

Iya perangkat desa ikut berperan, karena sesuai ketentuan dan soalnya emang yang berperan penting itu perangkat desa.

\section{Kaur Pembangunan (Kamis, 19 April 2018 Pukul 07:40 WIB)}

Iya jelas itu berperan. Semua berperan tidak hanya saya selaku kaur pembangunan.

\section{Bendahara (Jum'at, 20 April 2018 Pukul 08:09 WIB)}

Iya berperan karena perangkat desa sebagai pengelola kegiatan.

2. Bagaimana kinerja perangkat desa dalam mengelola dana desa untuk mencapai tujuan dengan kebijakan yang ditetapkan oleh pemerintah?

Jawaban:

\section{Kepala Desa (Senin, 30 April 2018 Pukul 07:58 WIB)}

Kinerja perangkat desa baik sesuai peraturan pemerintah, mereka bekerja sama karena setiap bidang memiliki tugas masing-masing.

\section{Sekreratis Desa (Rabu, 18 April 2018 Pukul 09:53 WIB)}

Dana desa yang diperoleh sudah ada instrumen untuk pengelolaannya. dan dalam mengelola dana desa, dana itu digunakan untuk pembangunan dan mensosialisasikan dengan masyarakat. Perangkat desa mensosialisasikan tujuan dari dana desa yaitu untuk pembangunan desa.

\section{Kaur Keuangan (Kamis, 19 april 2018 pukul 09:15 WIB)}

Di lapangan itu pasti terdapat kendala tapi bagaimana cara kita menyikapi kendala tersebut. Misalnya kaya pembangunan yang kurang dana atau material itu bagaimana caranya agar bisa mengatasi kendala tersebut.

\section{Kaur Pembangunan (Kamis, 19 April 2018 Pukul 07:40 WIB)}

Kalau di bangunan ada RAB dan sudah ada aplikasi jadi gak bisa melenceng, harus sesuai RAB yang ditetapkan.

Bendahara (Jum'at, 20 April 2018 Pukul 08:09 WIB)

Kinerja sudah maksimal. 


\section{Pelaporan}

1. Siapa saja yang ikut berperan dalam menyampaiakan laporan realisasi apbdes kepada bupati barito utara utara berupa laporan semester pertama dan laporan semester akhir?

Jawaban:

\section{Kepala Desa (Senin, 30 April 2018 Pukul 07:58 WIB)}

Yang ikut berperan itu saya sendiri sebagai kepala desa, sekretaris desa, bendahara, dan perangkat yang ada yang memiliki peran masing-masing.

Sekreratis Desa (Rabu, 18 April 2018 Pukul 09:53 WIB)

Yang ikut berperan itu kepala desa dan PTPKD, yaitu pelaksana teknis pengelolaan keuangan desa yang terdiri dari sekretaris desa, kepala seksi, dan bendahara.

\section{Kaur Keuangan (Kamis, 19 april 2018 pukul 09:15 WIB)}

Yang ikut berperan itu kepala desa, sekretaris desa, kaur keuangan dan bendahara desa.

\section{Kaur Pembangunan (Kamis, 19 April 2018 Pukul 07:40 WIB)}

Yang ikut berperan itu kepala desa, sekretaris desa, kaur keuangan dan bendahara desa.

\section{Bendahara (Jum'at, 20 April 2018 Pukul 08:09 WIB)}

Yang ikut berperan itu kepala desa, PTPKD. Dan kepala desa yang melaporkan kepada bupati sebagai penanggung jawab.

2. Apakah dalam menyampaikan laporan realisasi APBDesa dan laporan penyelenggaraan pemerintah desa pernah mengalami keterlambatan?

Jawaban:

\section{Kepala Desa (Senin, 30 April 2018 Pukul 07:58 WIB)}

Kadang pernah, karena waktu, situasi dan kondisi. Semua desa sama jarang yang tepat waktu.

\section{Sekreratis Desa (Rabu, 18 April 2018 Pukul 09:53 WIB)}

Pernah, karena akses dan kendala SDM. Apalagi baru menggunakan siskeudes, karena siskeudes yang baru dan pelatihan baru di ikuti sehingga belum dapat dilaksanakan karena keterbatasan SDM. Kami mengakui keterlambatan karena memang keadaannya seperti itu.

\section{Kaur Keuangan (Kamis, 19 april 2018 pukul 09:15 WIB)}

Realisasi gak pernah karena itu yang lebih utama untuk pengeluaran dana. Kalo dalam laporan penyelenggaraan pernah karena melalui aplikasi jadi gak mudah. 


\section{Kaur Pembangunan (Kamis, 19 April 2018 Pukul 07:40 WIB)}

Keterlambatan pada pencairan dana sehingga sulit membuat laporan dan di buat melalui aplikasi yang kadang ada perubahan sehingga memperlambat pelaporan.

Bendahara (Jum'at, 20 April 2018 Pukul 08:09 WIB)

Pernah, karena kami kan jauh dan SDM yang masih belum memadai.

\section{Pertanggungjawaban}

1. Bagaimana peran perangkat desa dalam melaksanakan prinsip akuntabilitas dalam pengelolaan dana desa?

Jawaban:

\section{Kepala Desa (Senin, 30 April 2018 Pukul 07:58 WIB)}

Tanggung jawab bersama, apa yang sudah dikerjakan merupakan peran perangkat desa karena semua masuk dalam tim.

\section{Sekreratis Desa (Rabu, 18 April 2018 Pukul 09:53 WIB)}

Untuk pertanggungjawaban berorientasi pada visi dan misi desa sesuai dengan RAB yang ada. Karena pada intinya dana desa merupakan amanah dari pemerintah pusat kepada pemerintah desa.

\section{Kaur Keuangan (Kamis, 19 april 2018 pukul 09:15 WIB)}

Apa yang sudah terencana harus tercapai harus terealisasi, kalau sudah harus ada laporannya.

\section{Kaur Pembangunan (Kamis, 19 April 2018 Pukul 07:40 WIB)}

Kalau sudah menyusun rencana lalu melaksanakan pembangunan sesuai RAB dan bentuk pembangunan dana harus disesuaikan RAB.

\section{Bendahara (Jum'at, 20 April 2018 Pukul 08:09 WIB)}

Dikelola semaksimal mungkin.

2. Apakah laporan realisasi pelaksanaan APBDes disampaikan secara tepat waktu? Jawaban:

Kepala Desa (Senin, 30 April 2018 Pukul 07:58 WIB)

Realisasi tepat waktu karena itu realisasi harus tepat waktu yang lambat itu LPJ nya.

Sekreratis Desa (Rabu, 18 April 2018 Pukul 09:53 WIB)

Tepat waktu, karena harus disampaikan akhir tahun. Laporan realisasi yang manual duluan karena untuk tahap 2 harus ada laporan realisasi dulu.

\section{Kaur Keuangan (Kamis, 19 april 2018 pukul 09:15 WIB)}

Iya disampaikan Tepat waktu, karena laporan realisasi pelaksanaan APBDes itu adalah syarat agar dana bisa keluar. 
Kaur Pembangunan (Kamis, 19 April 2018 Pukul 07:40 WIB)

Iya disampaikan Tepat waktu, kadang sebelum itu sudah di umumkan.

Bendahara (Jum'at, 20 April 2018 Pukul 08:09 WIB)

Kadang lambat kadang tepat wa 